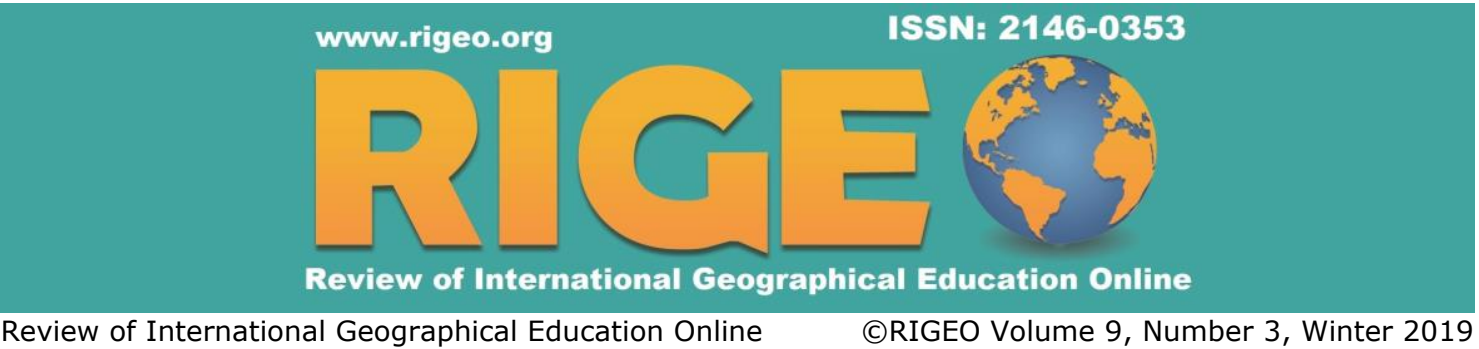

Research Article

Copyright @ RIGEO 2019

To cite this article: Seyhan, A. (2019). Out-of-School Learning to Achieve the Spatial Perception Skills: A Case Study. Review of International Geographical Education Online (RIGEO), 9 (3), 618-638. Retrieved from http://www.rigeo.org/vol9no3/Number3Winter/RIGEO-V9-N3-8.pdf

DOI: $10.33403 /$ rigeo.601734

Submitted: August 5, 2019

Revised: October 26, 2019

Accepted: November 28, 2019

\title{
Out-of-School Learning to Achieve the Spatial Perception Skills: A Case Study
}

\author{
Ayşe SEYHAN ${ }^{1}$ \\ Recep Tayyip Erdoğan University, Rize, TURKEY
}

\begin{abstract}
The cognitive depiction and comprehension of the structure, existence and relations of a place and its reflection and restructuring in the mind of a place is called spatial perception. Individuals' perceptions of place vary according to their environmental awareness, knowledge and impressions. The ability of individuals to perceive their surroundings, adapt to the places they are in and regulate their lives better depends on the sophistication of their perceptions of spatial. In order to develop the ability to perceive spatial, spatial skills such as spatial depiction, spatial representation, spatial analysis, and spatial evaluation need to be developed. The fact that the characteristics of the spatial give an idea of how the place can be perceived and the interaction of the individual with the place is important in developing the perception skills of the spatial brings to the fore out-of-school learning. The aim of this study is to examine the effects of the activities of a social studies education project carried out within the scope of TÜBITAK 4004 Nature Education and Science Schools Support Program on the ability to perceive spatial and the use of outdoor school places in the teaching of this skill. The study was conducted with a case study, one of the qualitative research types. The study group consisted of 30 teacher candidates selected by criterion sampling. The data obtained by open-ended questionnaire and document analysis were evaluated by content analysis. The research also shows that the activities applied according to the findings are effective in teaching the perception of spatial and the ability to perceive place. Teacher candidates have stated that they are able to recognize the place, objects and assets around them through activities outside the school and improve their perception skills by applying them.
\end{abstract}

Keywords

Perception Skills, Out-Of-School Social Studies, Skill, Teacher Candidates, Case Study

Social studies is a lesson which is formed by bringing together the disciplines of social sciences in order to gain basic knowledge, skills, attitudes and values about the

${ }^{1}$ Assist. Prof., Recep Tayyip Erdogan University, Çayeli Educational Faculty, Turkish and Social Sciences Department, RizeTurkiye, ayse.seyhan [at] erdogan.edu.tr , ORCID: 0000-0003-1741-4878

(C) Review of International Geographical Education Online RIGEO 2019 ISSN: 2146-0353 
social life to the individual, to educate a good, responsible citizen and to realize the social existence of the individual (Ministry of National Education [MoNE], 2005). The social studies curriculum developed in accordance with constructivist understanding as of 2005 and recently revised in 2018, includes competencies, values and skills that are intended to be acquired by the students (MoNE, 2018). Skill is the performance demonstration, development and use of gained knowledge in life (MoNE, 2005). Paykoç (1991) expressed that the skill is to be able to perform any activity continuously at a certain level of competence. In the dictionary of Turkish language institution (TLI, 2018), place is defined as "place", "house", "home", "space".

Hasol (2016) cites the concept of place as "a place that separates the person from the environment to a certain extent and within it is conducive to his or her various actions." The concept of place is classified in different ways in the literature. Montello (1993) divided the place into four categories according to their size; formal, landscape, environmental and geographical locations. It is important to note that the size of a body, such as pictures and small objects, is smaller than the size of a body and can be perceived without the need for significant movement; formal places, places that are close to or slightly larger than their body sizes in size, where rooms, towns, or small valleys can be cited as examples; landscape places, buildings, neighborhoods and cities, such as the body with larger dimensions, environmental places, countries, states, the solar system, such as a view or through the movement of large areas as the geographical places explained. Roth (2000) states that the places whose boundaries can be determined by visual means are physical place, the places without visual boundaries, which are transparent to reach the extreme points of the eye, are perceived as perceptual place, and the places stored in memory in relation to the perceptual place are conceptual places. Avar (2009) divided places into two classes, abstract and concrete places. He stated interior and exterior places as concrete places, the fictional places that individuals create in their own thoughts, which do not actually exist in real life, and abstract places.

The cognitive depiction and comprehension of the structure, existence and relations of a place and its reflection and restructuring in the mind of a place is called spatial perception (Öcal, 2011). Spatial perception is realized by gaining experience and remembering the place within or around the place for a period of time (Özen, 2006). Spatial perception includes skills such as hand-eye coordination, shape-ground perception, perceptual continuity, and location in place, visual discernment, visual memory, and perception of spatial relationships (Özdemir, 2011). Perception defined as sensory information about abstract and concrete objects in the outside world, occurs through the active reading of Environmental Information through the sense of hearing, tasting, seeing, sniffing, touching and feeling (Özen, 2006; İnceoğlu, 2011; Solak, 2017). As place begins to be defined by the senses, spatial perception or environmental perception arises.Individuals in order to survive and understand the world around them, spatial perception, spatial depiction, spatial representation, spatial analysis, spatial assessment, spatial skills, such as the position of the object along with other objects and between objects associating it with the location of its position, location, distance, shape, analyze spatial relationships, such as region, giving directions for the navigation are required to acquire skills (Schultz, Kerski, and Patterson, 2008; Öcal, 2009; Özdemir, 
2011). Spatial perception skills includes the ability to visualize the shape of an object in space or a shape on paper, to see a shape in three dimensions, to see the space relations that enable to portray an area, sketch, street or building in the mind, to draw and interpret maps, plans, sketches, graphs, diagrams, and to use spheres (MoNE, 2005). Place perception of individuals change according to their awareness, knowledge and impressions about the environment. In addition to these feelings, attitudes and beliefs and the appearance, structure, character and function of that place also affect the spatial perceptions of individuals (Golledge and Stimson 1997; Solak, 2017; Baksi, 2018).

Individuals' ability to observe, perceive, notice detail and use imagination, as well as their personal experiences, social and cultural experiences cause different perceptions of place (İnceoğlu, 2011; Asar, 2013). Because, knowledge of place with these skills and all kinds of experiences accumulated by the perceiver are made sense in a cognitive process. Therefore, it is necessary to increase the perception thresholds and awareness of individuals with the mentioned skills in order to improve the spatial perception. In order for a place to be perceived, the person to perceive must be able to read the qualitative characteristics of the place by blending it with her/his own life and experiences. Because people's perception of place depends on their knowledge of the physical properties of that place, people's perception of this place is effective in evaluating that place. The individual's spatial perception also affects their behavior towards that place spatial perception (Özen, 2006).

An individual who has developed the spatial perception skills place can read the drawings of the place well and draw concrete, three-dimensional events and phenomena around. One can easily comprehend the relationship between assets by comparing a place with its shape drawn on paper. Perception of geographical concepts is possible by explaining the relationships between these concepts and their reasons and results (MoNE, 2005). Individuals should acquire the ability to perceive place at an early age as they begin to understand human and environmental relations from infancy and to learn their place in the world. Because, individuals are curious about nature and try to use all their senses to explore nature (Gandy, 2007; Çukur and Delice, 2011). Individuals who have the ability to perceive the place can perceive the environment better, adapt to the place more easily and organize their lives better. Daily activities and behaviors, such as driving, organizing the house, choosing the best route to the beach, remembering where the keys were left, finding what you were looking for in shopping, are associated with the use of the ability to perceive the place (Hespanha, Goodchild, and Janelle 2009).

The perception of place nourishes individuals ' sense of commitment and belonging to the place and makes the individual an element of that place. Individuals who have the perception of place feel entitled and responsible for the place they are in (Solak, 2017). In addition, the quality of the relationship established by the individual with the place, the senses created by the person with the place, the communication of the person with the place determines the commitment to the place (Gezer, 2012). For individuals to establish a spatial relationship with a place, they need to move actively in that place and accumulate various images in their minds. For the realization of spatial perception, the perceptual relationship with the places must be established qualitatively correctly (Asar, 
2013). Since spatial perception is related to skill acquisition, it is important to teach on real places and real objects (Şengül Bircan and Safran, 2013).

The National Council for Social Studies (NCSS, 2014) and [NCSS] states that teachers should organize activities in such a way that they can create psychological and physical bonds and interact with the environment and places to create a sense of place in children. The learning areas and skills of the social studies curriculum developed in line with the principles of the National Council of Social Studies support the education with real places and objects to a large extent. The special aims of the program are to explain the interaction between human and environment by recognizing the general geographical features of the environment and the world in which the students live, and to improve the spatial perception skills. "The spatial perception skills in the program is matched by the learning outcome of "The People, Places and Environments" learning area (MoNE, 2018). The learning outcomes and grade levels related to the spatial perception skills in the social studies course curriculum are given in Table 1.

Table 1

The learning outcomes and grade levels related to the spatial perception skills

Learning Area/ Grade No/ The Learning Outcome

\begin{tabular}{|c|c|c|}
\hline \multirow{7}{*}{ 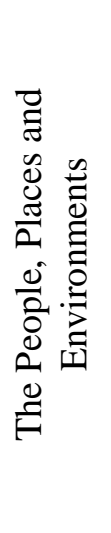 } & 4. & 1. It is found in inferences about the location of any location around it. \\
\hline & 4. & 2. It draws a sketch of the places used in daily life. \\
\hline & 4. & $\begin{array}{l}\text { 3. It distinguishes natural and human elements in environment in which it } \\
\text { lives. }\end{array}$ \\
\hline & 4. & $\begin{array}{l}\text { 5. It makes inferences about the landforms and population characteristics } \\
\text { of its habitat and surrounding areas. }\end{array}$ \\
\hline & 5 . & $\begin{array}{l}\text { 1. It explains the earth shapes of the place where he/she lives and its } \\
\text { environment on maps in general. }\end{array}$ \\
\hline & 6. & $\begin{array}{l}\text { 2. It examines the basic physical geography features of Turkey, landforms, } \\
\text { climate features and vegetation on related maps. }\end{array}$ \\
\hline & 7. & $\begin{array}{l}\text { 1. It is found in inferences about factors affecting settlement from past to } \\
\text { present through sample investigations. }\end{array}$ \\
\hline
\end{tabular}

In the literature, the effectiveness of different methods, techniques, materials and activities related to the development of the spatial perception skills in students was examined. The use of maps, graphics, diagrams, spheres, map interpretation and map drawing for developing the spatial perception skills in these researches (Yaz1c1, 2006; Şengül, Bircan and Safran 2013), animation and use of digital maps (Aktürk, Yazıcı and Bulut 2013), animation and digital maps (Aktürk, 2012), mind map (Taş, 2008; Kan, 2012), aerial photographs (Öcal, 2009), Geographic Information System (GIS) (Demirci ve Karaburun 2011; Milson and Earle 2008), Use of google earth (Öğütveren, 2014), virtual land trips (Çalışkan, 2011), activities outside the classroom (Altın and Demirtaş, 2009), historical places (Çulha, 2006) and spatial skills training (Özdemir, 2011) the effects of methods, techniques, activities and materials were examined and These methods / techniques, materials and activities were found to improve students' perception of place skills. Gold and et al. (2018) suggest that spatial thinking is more advanced in men because of their playing computer games associated with structure and 
sports. Ishikawa (2016) states that students' ability to thematic map reading and understand the conceptual terms of maps varies depending on their spatial visualization abilities. The qualitative properties of place (texture, material, color, light, digital factors) provide the person with insights into how that place can be perceived. Individuals are constantly interacting with their environment through this spatial perception (Avar, 2009 and Özen, 2006). The spatial perception skills takes place in the form of sensing abstract and concrete objects, hearing, tasting, seeing, smelling, touching and feeling, as well as reading environmental knowledge through a mental process. The individual moves through place, accumulating various images in his mind and begins to establish a spatial relationship with that place. For the individual to establish a spatial relationship with a place, he/she should play an active role in that place and he/she should act in it (Asar, 2013). Spatial thinking in the social sciences is a useful tool for the discovery and understanding of new knowledge (Hespanha, Goodchild, and Janelle 2009). It is important that out-of-school learning is put to work and disseminated in order to gain spatial thinking to the students. Thus, in social studies curriculum, students are expected to explain the interaction between human and environment by recognizing the general geographical features of the world and the environment in which they live, and to develop their ability to perceive place (MoNE, 2018). Various methods, techniques and materials have been used to improve students' perception of place and it is observed that the studies conducted in out-of-school places are inadequate. So, in this study examined how the education that social studies teachers see in out-of-school places affects their ability to perceive place. Also, the students' opinions regarding the development of the spatial perception skills were also taken. Accordingly, the following questions were sought:

1. Where is the place according to social studies teacher candidates?

2. What are the similar and different aspects of place-landscape and scene concepts according to social studies teacher candidates?

3. What are the understanding and interpretation skills of individuals who have a perception of place according to social studies teacher candidates?

4. What are the suggestions of social studies teacher candidates for improving the perception of place in individuals?

\section{Methodology}

\section{Research Design}

This study was conducted by using case study which is one of the qualitative research designs. Case study is a qualitative research approach in which one or more cases are examined in depth based on extensive data collection. The case subject to the study may be a single individual or individuals individually or within a group, a program, events or activities (Creswell, 2017). The research is an example of a case study created to determine the views of social studies teacher candidates who are studying in the field of social studies education regarding the teaching of the spatial perception and the spatial perception skills and to examine the process. Case study is a method in which a current phenomenon is studied within its own reality. This method is a type of empirical research done when boundaries are unclear between fact and context 
(Yin, 2017). The stages that can be followed in the case study are shown below (Yıldırım and Şimşek, 2016):

Table 2

Case Study Process

\begin{tabular}{ll}
\hline Case & Study Process \\
\hline 1. & Development of research questions \\
2 & Development of sub-problems of research \\
3 & Determination of the analysis unit \\
4 & Determination of the situation to be studied \\
5 & Selection of individuals to participate in the research \\
6 & Collecting data and correlating the collected data with sub-problems \\
7 & Data analysis and interpretation \\
8 & Reporting the case study \\
\hline
\end{tabular}

\section{Participants}

The participant group consists of 30 teachers from Turkish and Social Studies Education Departments of the education faculties of universities in Turkey. According to Büyüköztürk, Çakmak, Akgün, Karadeniz and Demirel (2011), criterion sampling can be used in a research if observation units consist of individuals, events, objects or situations with certain qualifications. In this study, the selection of participants is based on volunteerism, (i) having not participated in a similar type of educational project before, (ii) herhangi bir disiplin cezası almamış olma, (iii) katılım isteğini gerekçelendirme ve (iv) not having a health problem, these conditions reflect the characteristics of criterion sampling. 21 female and 9 male teacher candidates from 10 different universities participated in this project. 6 of the participants are 2nd grade, 20 of them are 3rd grade, 4 of them are in 4 th grade. The teacher candidates' information was displayed in Table 2.

Table 2

Information about the Social Studies Teacher Candidates

\begin{tabular}{lccclc}
\hline Cinsiyet & $\mathrm{f}$ & $\begin{array}{c}\text { Grade } \\
\text { Level }\end{array}$ & $\mathrm{f}$ & University & $\mathrm{f}$ \\
\hline Female & 21 & 2 & 6 & Artvin Çoruh University & 1 \\
Male & 9 & 3 & 20 & Atatürk University & 1 \\
& & 4 & 4 & Bolu Abant İzzet Baysal University & 2 \\
& & & Gazi University & 6 \\
& & & İstanbul University & 5 \\
& & & Marmara University & 2 \\
& & & Nevşehir Hac1 Bektaş Veli University & 3 \\
& & & Recep Tayyip Erdoğan University & 6 \\
& & & Tokat Gaziosmanpaşa University & 3 \\
Total & & & Yldiz Teknik University & 1 \\
\hline
\end{tabular}




\section{Research Implementation Process}

This research was carried out under the project "Out-of-School Education Practices in Social Studies Teaching", supported by the scientific and technological research council of Turkey (4004) under the call of 2018 and carried out in June 2019. Activities were prepared by the researcher taking into account the learning outcomes, skills and values of the social studies course curriculum prior to the application. Lesson activities were also enriched during the pilot practice in the learning areas. The activities performed during the 6-day project to improve the ability to perceive the place are shown in Table 3.

Table 3

Implemented Activities and Studies

\begin{tabular}{|c|c|c|c|c|}
\hline Day & Name of Activity & The Studies & Location of the Event & Lesson Time \\
\hline Day 1 & Natural Disasters & $\begin{array}{l}\text { Environmental observation } \\
\text { Interview } \\
\text { Discussion }\end{array}$ & Gündoğdu & 2 \\
\hline \multirow[t]{2}{*}{ Day 2} & Madrasahs & $\begin{array}{l}\text { Cooperative learning } \\
\text { application } \\
\text { Observation } \\
\text { Worksheet activities } \\
\text { Drawings in real places }\end{array}$ & $\begin{array}{l}\text { Çukurluhoca } \\
\text { Madrasah }\end{array}$ & 3 \\
\hline & Bridge Activity & $\begin{array}{l}\text { Observation } \\
\text { Architectural drawings } \\
\text { Worksheet }\end{array}$ & $\begin{array}{l}\text { Historical Muradiye } \\
\text { Bridge }\end{array}$ & 2 \\
\hline \multirow[t]{2}{*}{ Day 3} & Castle Activity & $\begin{array}{l}\text { Observation } \\
\text { Cooperative learning } \\
\text { Worksheet activities } \\
\text { Real place drawings }\end{array}$ & Rize Castle & 2 \\
\hline & Cave Activity & $\begin{array}{l}\text { Observation form } \\
\text { Interview } \\
\text { Discussion }\end{array}$ & Çal Cave & 2 \\
\hline \multirow[t]{4}{*}{ Day 4} & $\begin{array}{l}\text { Geographic Area } \\
\text { Activity }\end{array}$ & $\begin{array}{l}\text { Geographical field } \\
\text { observations } \\
\text { Geographical observation } \\
\text { form } \\
\text { Geographic place drawings }\end{array}$ & Firtına Valley & 4 \\
\hline & Konaklar Etkinliği & $\begin{array}{l}\text { Observation } \\
\text { Worksheet } \\
\text { Oral history } \\
\text { Architectural drawings }\end{array}$ & Memiş Ağa Mansion & 2 \\
\hline & $\begin{array}{l}\text { Botanical Garden } \\
\text { Event }\end{array}$ & $\begin{array}{l}\text { Observation, Observation } \\
\text { form }\end{array}$ & $\begin{array}{l}\text { Trabzon Botanical } \\
\text { Garden }\end{array}$ & 2 \\
\hline & $\begin{array}{l}\text { Oryantiring } \\
\text { Activitiy }\end{array}$ & $\begin{array}{l}\text { Location-direction finding, } \\
\text { using compass and map } \\
\text { reading activity } \\
\text { Orienteering competition }\end{array}$ & $\begin{array}{l}\text { RTEÜ BESYO } \\
\text { Orienteering Area }\end{array}$ & 3 \\
\hline Total & & & & 22 \\
\hline
\end{tabular}

Some visuals from the activities are shown in Figure 2, Figure 3 and Figure 4. 

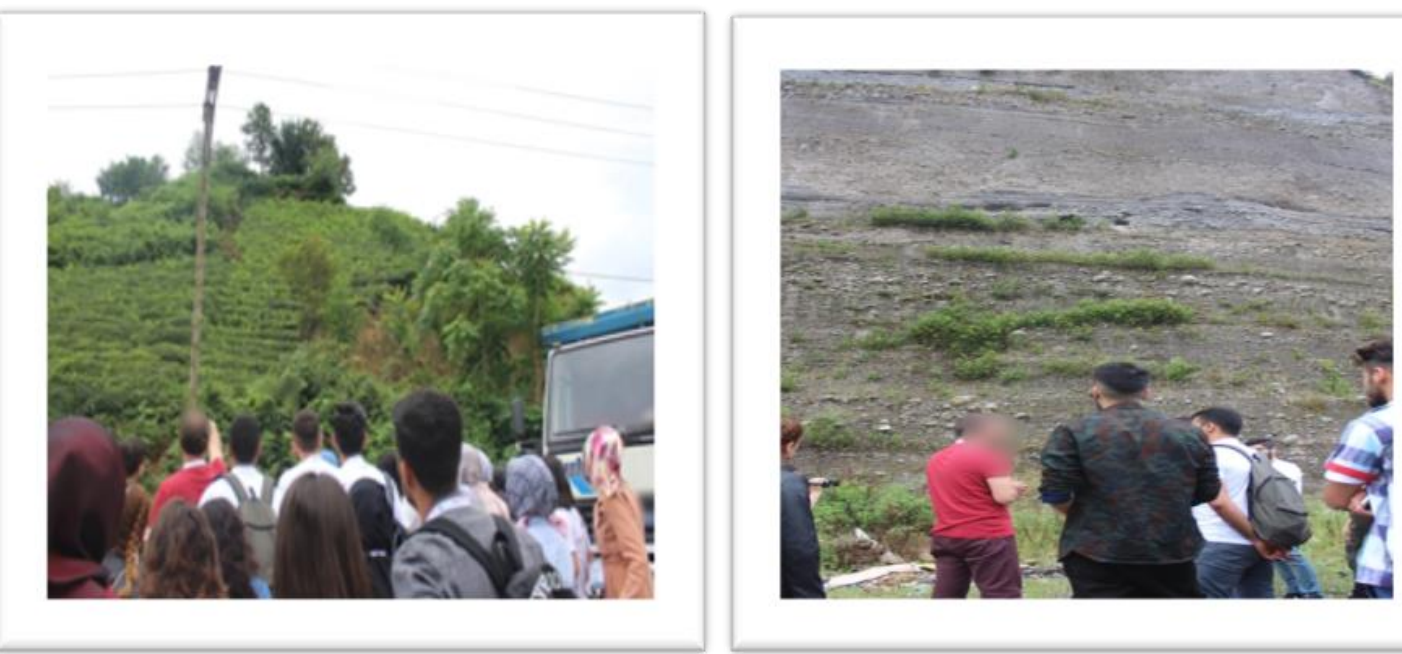

Figure 2. Images from nature observation activity
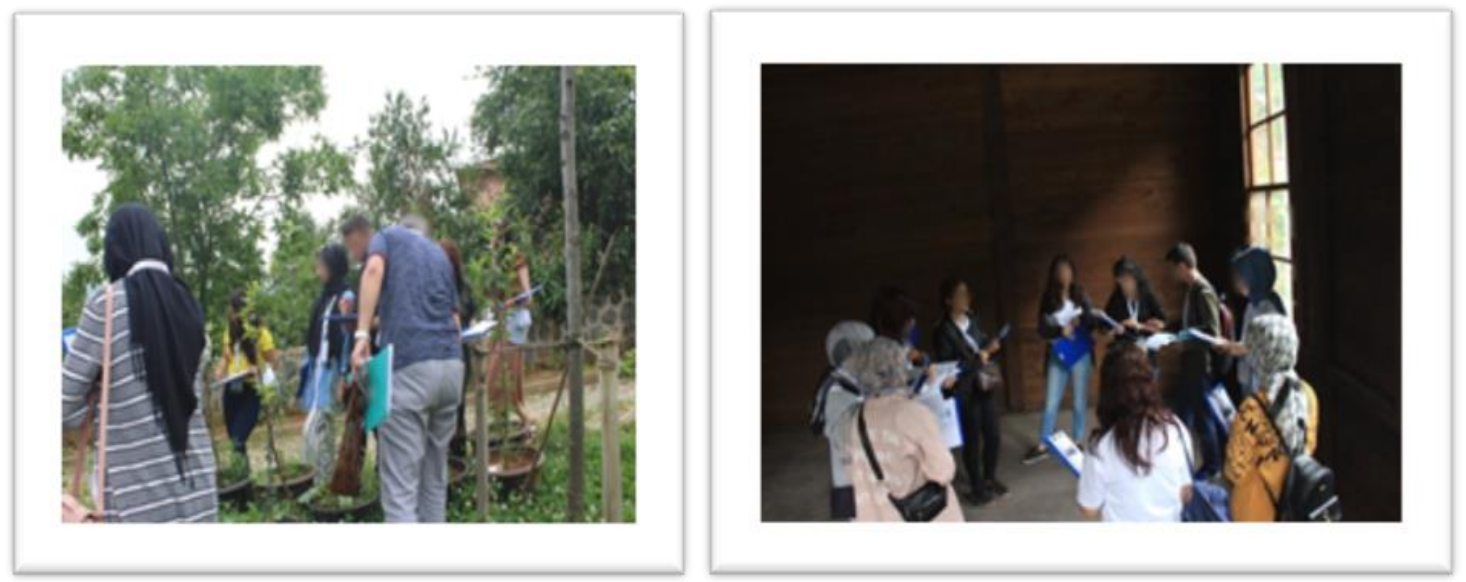

Figure 3. Images from the botanical garden and madrasa activitiy
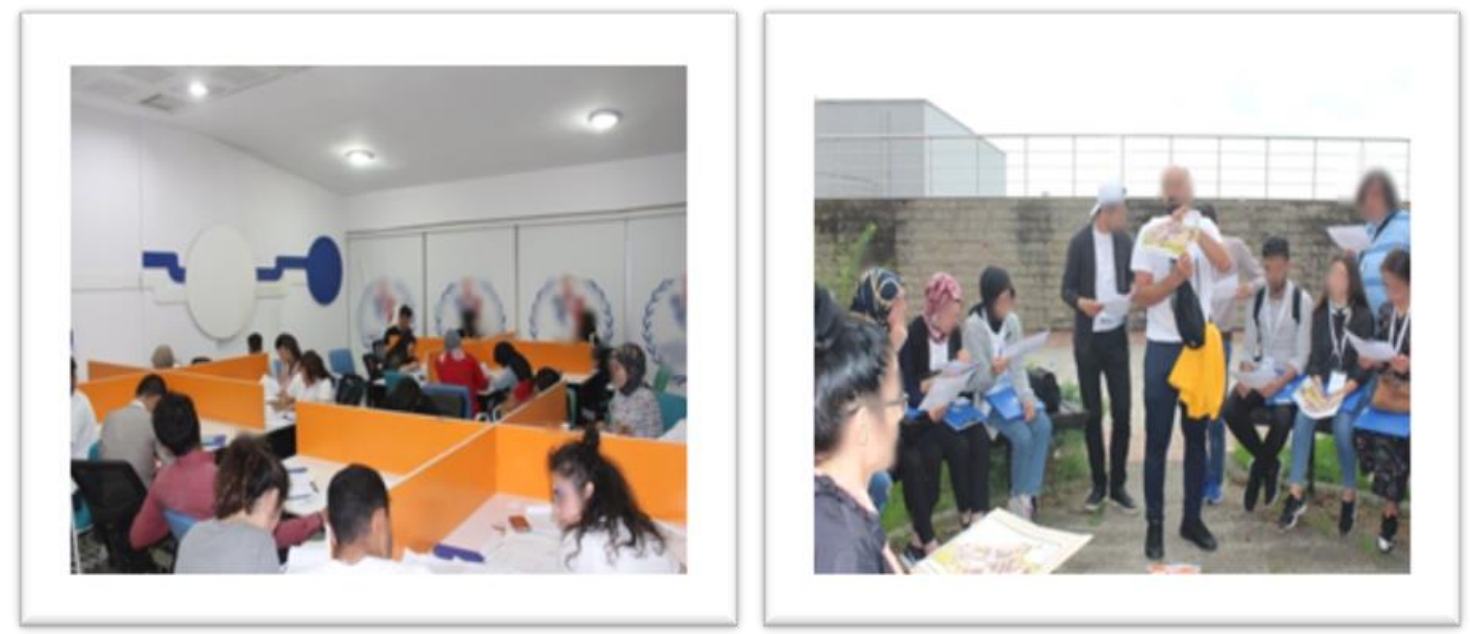

Figure 4. Images from orienteering and working paper activity 


\section{Data Collection Instruments}

Research data was collected through document review and interview form consisting of open-ended questions. The first data source of the research is the interview form. Interview form has been created from four questions in accordance with the activities. Teacher candidates' perceptions of place, their knowledge about place elements, their opinions about the development of place perception, understanding and interpretation skills of individuals with place perception and suggestions to improve their perception of place consists of questions. The interview form is presented to the opinions of three researchers who are social studies education, Turkish education and assessment and evaluation experts for their validity and reliability. The questions on the form were checked for intelligibility and age group compliance and a pilot application was carried out. After the pilot application, the questions were corrected and the interview form was given its final form. This form was applied to teacher candidates after the activities were carried out. Araştırmanın This form was applied to teacher candidates after the activities were carried out. The secondary data collection tool has created reflecting writing posts from participants. One of the ways to increase validity and reliability in case study is data triangulation (Yıldırım and Şimşek, 2016). In this research, the data collected by the interview form was supported with documents and tried to increase validity and reliability.

\section{Data Analysis}

Content analysis was used in the analysis of data in the research. Content analysis is carried out in four stages: coding the data, finding the themes, editing the codes and themes, defining and interpreting the findings (Yıldırım and Şimşek, 2016). In order to increase the validity and reliability of the data analysis, the data obtained were read by two researchers and the themes and codes of these data were determined. Similar answers are grouped and categories are formed. The reliability formula (reliability= consensus / consensus + dissidence) developed by Miles and Huberman (2006) was used by by two researchers. The compatibility between the two encoders was calculated to be $84 \%$. The categories and response frequencies are digitized and given in the frequency (f) tables. Also, teacher candidates' answers to each question were directly quoted directly. The direct sentences of the teacher candidates are encoded with a specific number in the order in which they deliver the form while being transferred from the forms. After these code numbers, the letter $M$ for male and $F$ for female are determined. For example, S2-F code was determined for the female teacher candidate who submitted the questionnaire in 2 nd place.

\section{Findings}

In this section, themes are created for each question and the frequencies of codes for the created themes are given. Also, the responses of the teacher candidates were directly quoted. The findings are presented in Table 4. 
Table 4

The Findings about the Perceptions of Place the Teacher Candidates'

\begin{tabular}{|c|c|c|}
\hline \multicolumn{2}{|l|}{ Theme } & $\mathrm{f}$ \\
\hline \multirow{5}{*}{ 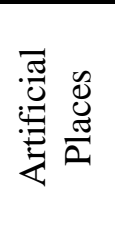 } & Living place, house & 10 \\
\hline & Where people's habitats are located & 7 \\
\hline & Cities & 6 \\
\hline & Buildings & 5 \\
\hline & Streets & 4 \\
\hline \multirow{6}{*}{ 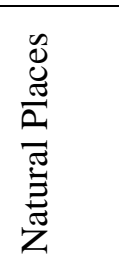 } & Universe & 9 \\
\hline & Area of human, animals and plants & 6 \\
\hline & Solar system & 5 \\
\hline & Planets & 5 \\
\hline & Moon and Earth & 4 \\
\hline & Mountains & 3 \\
\hline \multirow{4}{*}{$\frac{\bar{\Xi}}{\tilde{\Xi}}$} & Areas in which certain actions are performed & 6 \\
\hline & Areas where people are affected and affected & 4 \\
\hline & Everything that can be perceived & 3 \\
\hline & Every place people could notice & 3 \\
\hline
\end{tabular}

When it examined Table 4, teacher candidates ' perceptions of place are concentrated under three themes: "artificial places", "natural places" and "other". teacher candidates' place concept in terms of the theme "artificial places"; "living place, house" (10), "where people's habitats are located" (7), "cities" (6), "buildings" (5), "streets" (4), in terms of the theme of "natural places"; "universe" (9), "area of human, animals and plants" (6), "solar system" (5), "planets" (5), "moon and earth" (4), "mountains" (3) "other" theme; "areas in which certain actions are performed" (6), "areas where people are affected and affected" (4), "everything that can be perceived" (3), "every place people could notice" (3) they have defined it as.

In the light of the findings, it can be said that the teacher candidates often define the concept of place as places where people live and perceive it, while they view places as places where living things can live. It can be said that the participatory expressions related to the concept of place are similar to the definitions of place in the literature. (TLI, 2018; Hasol, 2016). Some of the statements of the teacher candidates are as follows:

"...Place is the habitat where humans, animals and plants live together ..." (S18, M).

"...Every place that people perceive; like the moon and the earth..." (S19, F).

"...Every place in the world is different places, for example; planets, seas, home, school..." (Ö23, K).

“...Places where people can live and feel comfortable..." (S30, F).

“...Everywhere that can be noticed by human intelligence is place ..." (S2, M).

"...To me, the world, the universe, is a place, Argentina is a place, Africa is a place" $(\mathrm{S} 1, \mathrm{M})$.

The findings are presented in Table 5. 
Table 5

Findings about Similarities and Differences of Place, Landscape and Scene Concepts

\begin{tabular}{|c|c|c|}
\hline Theme & Code & $f$ \\
\hline \multirow{9}{*}{ 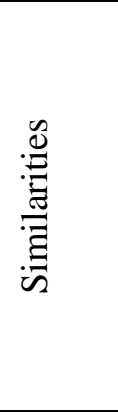 } & Landscape and scene coverage of the place & 20 \\
\hline & Specify an area & 13 \\
\hline & Being associated with the environment & 8 \\
\hline & They can be perceived & 5 \\
\hline & Being associated with architecture & 5 \\
\hline & Complementing each other & 4 \\
\hline & To impress each other & 3 \\
\hline & Being associated with nature & 2 \\
\hline & Human influences & 2 \\
\hline \multirow{10}{*}{ 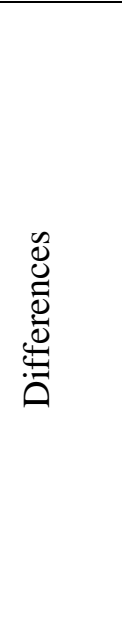 } & $\begin{array}{l}\text { Related to landscaping of landscape, the environmental beauty of } \\
\text { landscape }\end{array}$ & 14 \\
\hline & The landscape being by human intervention & 9 \\
\hline & Artistic and aesthetic beauty of the landscape according to the place & 8 \\
\hline & The place is more extensive than the landscape & 7 \\
\hline & Landscape with human intervention according to place & 7 \\
\hline & Landscape according to the place to be rural-looking & 5 \\
\hline & $\begin{array}{l}\text { How the landscape activates the individual's emotions according to the } \\
\text { landscape }\end{array}$ & 5 \\
\hline & $\begin{array}{l}\text { Differences in the perception of beauty in relation to the landscape } \\
\text { according to the individual }\end{array}$ & 4 \\
\hline & $\begin{array}{l}\text { The difference between the landscape and the place is based on the } \\
\text { construction }\end{array}$ & 4 \\
\hline & The definitions are different from each other & 3 \\
\hline
\end{tabular}

When it examined Table 5, teacher candidates stated the similarities of place, landscape and landscape as follows: "Landscape and scene coverage of the place" (20), "specify an area" (13), "being associated with the environment" (8), "they can be perceived" (5), "being associated with architecture" (5), "complementing each other" (4), "to impress each other" (3), "being associated with nature" (2), "human influences" (2). According to these findings, it is understood that the teacher candidates ' definitions of place, landscape and landscape concepts mainly cover landscape and landscape, these concepts indicate an area, they can be perceived with human senses, the concepts are related to each other, and they think that these three concepts represent beauty.

Teacher candidates' views on different aspects of place, landscape and landscape concepts; "Related to landscaping of landscape, the environmental beauty of landscape" (14), "The landscape being by human intervention" (9), "Artistic and aesthetic beauty of the landscape according to the place" (8), "The place is more extensive than the landscape" (7), "Landscape with human intervention according to place" (7), "Landscape according to the place to be rural-looking" (5), "How the landscape activates the individual's emotions according to the landscape" (5), "Differences in the perception of beauty in relation to the landscape according to the individual" (4), "The difference between the landscape and the place is based on the construction" (4), "The definitions are different from each other" (3). Based on these findings, it is understood 
that the teacher candidates perceive place as a place that covers a larger area than the concept of landscape and landscape, the landscape as self-formed areas naturally, and the landscape as an architectural arrangement of natural or artificial areas. Some of the statements of the teacher candidates are as follows:

"...The beauty of a place is landscape, the beauty of the landscape is caused by the beauty of the scene..." (S1, M).

"...All three concepts are related to place, landscaped place can compose the scene, the scene can also be found naturally in the place. ..." (S2, M).

"...Landscape is a place and composes a scene, their common point is that they are detectable..." (S3, M).

"...These concepts are the name given to the general parts of a place, the general properties of a structure, these concepts cover each other..." (S6, F).

"...Scene is a remarkable state of landscape in place ..." (S7, F).

“...Scene shapes place ..." (S20, F).

"...All three concepts are related to nature. Landscape, scene and place are places where people feel what they see ..." (S24, M).

"...There is a general order between them as place-scene-landscape ..." (S28, F).

Some of the teacher candidates ' views on different aspects of place, landscape and scene concepts are as follows:

"...Place covers them all, while landscape is the beauty of the environment while landscape means landscaping..." (S1, M).

"...Scene can occur naturally or artificially, landscape does not occur naturally naturally, landscape may be a place while landscape may not be a landscape..." (S3, M).

"...Scene varies from person to person, place can be anything anywhere, the design of a place by nature is landscape..." (S7, F).

"Scene is a pleasant place. It is the arrangement of a place in the landscape to make the eye look pleasant..." (S10, M).

"...The place where we live, the landscape is a country-looking place, and the landscape is an area that looks beautiful from an artistic aesthetic point of view..."(S16, F).

"...Landscape is the zoned state of place, and landscape is what evokes emotion when we look at it..." (S19, F).

"Differently place is a more general expression, whereas landscape refers to a narrower area... " (S25, F).

"...They differ definitively and conceptually, though there is a correlation between them ..." (S26, M).

The findings are presented in Table 6. 
Table 6

Findings about the Understanding and Interpretation Skills of Events Individuals' With Place Perception

\begin{tabular}{|c|c|c|}
\hline Theme & Code & $\bar{f}$ \\
\hline \multirow{5}{*}{ 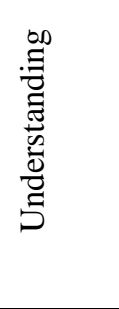 } & $\begin{array}{l}\text { To be able to examine social, cultural and economic situations from } \\
\text { different perspectives }\end{array}$ & 4 \\
\hline & To be able to be aware of the details of the place & 3 \\
\hline & To be able to understand different points of view & 2 \\
\hline & $\begin{array}{l}\text { To be able to understand the feelings and thoughts of the people living in } \\
\text { the place }\end{array}$ & 2 \\
\hline & To be able to comprehend the factors affecting the place & 1 \\
\hline \multirow{5}{*}{ 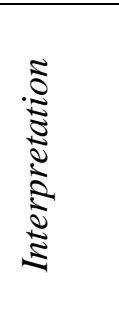 } & Easier, comprehensive and accurate interpretation of events & 8 \\
\hline & To be able to evaluate events by knowing and understanding & 4 \\
\hline & $\begin{array}{l}\text { To be able to consider the conditions of the place when evaluating the } \\
\text { events }\end{array}$ & 3 \\
\hline & $\begin{array}{l}\text { To be able to analyze geography according to cause and effect } \\
\text { relationship }\end{array}$ & 3 \\
\hline & To be able to interpret place from part to all & 1 \\
\hline \multirow{9}{*}{ 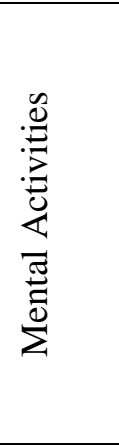 } & $\begin{array}{l}\text { To be able to organize activities in education from close environment to } \\
\text { far environment }\end{array}$ & 6 \\
\hline & Having high imagination & 5 \\
\hline & To be curious & 5 \\
\hline & Development of concrete and abstract ideas & 4 \\
\hline & To be able to describe place & 4 \\
\hline & To be able to think objectively & 3 \\
\hline & Development of worldviews & 2 \\
\hline & Development of mental skills & 2 \\
\hline & Development of inquiry skills & 1 \\
\hline
\end{tabular}

When it examined table 6 , teachers candidates' opinions about the understanding and interpretation skills of individuals with a perception of place are stated under three themes; "understanding", "interpretation"and "mental activities". Teacher candidates 'views under the theme "understanding"; "to be able to examine social, cultural and economic situations from different perspectives" (4), "to be able to be aware of the details of the place" (3), "to be able to understand different points of view" (2), "to be able to understand the feelings and thoughts of the people living in the place" (2) and "to be able to comprehend the factors affecting the place" (1). teacher candidates 'views under the theme "interpretation"; "easier, comprehensive and accurate interpretation of events" (8), "to be able to evaluate events by knowing and understanding" (4), "to be able to consider the conditions of the place when evaluating the events" (3), "to be able to analyze geography according to cause and effect relationship" (3) ve "to be able to interpret place from part to all" (1). Teacher candidates 'views under the theme "mental activities"; "to be able to organize activities in education from close environment to far environment" (6), "having high imagination" (5), "to be curious" (5), "development of concrete and abstract ideas" (4), "to be able to describe place" (4), "to be able to think objectively" (3), "development of worldviews" (2), "development of mental skills" (2) ve "development of inquiry skills" (1). 
Teachers' candidates' answers to the understanding and interpretation skills of individuals with place perception are as follows:

"...Students who perceive the place well can understand the lifestyle of the people who live in that place..." (S1, M).

"... Evaluate events and situations taking into account the circumstances of the venue $\ldots "(\mathrm{~S} 3, \mathrm{M})$.

"... The perception of place adds to the child's worldview as well and helps him study geography according to cause and effect relation... " (S4, M).

"...Students question more and place meaning in what is happening around them..."(S5, F).

"...Is a perception that comes out by visiting and seeing the place and supporting the imagination of the people. The more the person observes the trip, the more he / she becomes conscious about the place and his / her perception develops..." (S6, F).

"...Comprehends its connections with the elements affecting place..." (S8, F).

"...One who perceives the place culture economy of the place can also comment on the lives of people..." (S11, F).

"...Students who have the perception of place can first examine the place piece by piece and then as a whole. This is a private-to-general review, making it easier to connect ..." (S14, F).

"...Students who have a perception of place are more likely to examine events, criticize discussions than students who do not have this perception, they make comments knowing and understanding..." (S16, F).

"... They can understand more comprehensively the events in the environment in which they live " (S23, F).

"Students with a perception of place make more accurate determinations in reading, understanding and interpreting events... " (S1, M).

"...Students who have the perception of place understand and interpret the interaction of all living things in this place... " (S20, F).

"... Students who have a perception of place examine all the areas they have seen and make an inference, develop the ability to make final criticism... " (S21, F).

"...Students who can accurately perceive the place understand the events the way they occur will be able to more easily comprehend situations such as the causes of events..." (S22, F). M).

"... Comprehends that there is a strict relationship between nature and man ... " (S24,

“... A student with a perception of place mentally developed abstract and concrete thoughts" understanding and interpreting skills developed and completed... " (S28, M).

"...The student has multiple perspectives, associates the past with the present, makes a socio-economic assessment of the region..." (S29, F).

The findings are presented in Table 7. 
Table 7

Suggestions for Improving the Perception of Place in Social Studies Teaching

\begin{tabular}{|c|c|c|}
\hline Theme & Code & $f$ \\
\hline \multirow{5}{*}{ 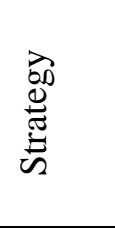 } & Developing imagination of students & 10 \\
\hline & Organizing activities appropriate to the age of the students & 6 \\
\hline & Teaching from concrete to abstract & 6 \\
\hline & Imagining the place visited to the students during abstract stage & 6 \\
\hline & Learning the story of places & 2 \\
\hline \multirow{8}{*}{ 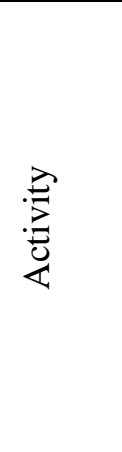 } & Making activity on real places & 27 \\
\hline & $\begin{array}{l}\text { Using map compass and location direction finding with orienteering } \\
\text { activity }\end{array}$ & 25 \\
\hline & $\begin{array}{l}\text { Organizing activities for the remote environment starting from the } \\
\text { immediate surroundings }\end{array}$ & 11 \\
\hline & Using three-dimensional images in the courses & 10 \\
\hline & Interpretation of photos & 9 \\
\hline & Drawing of real places & 6 \\
\hline & Environmental examination & 5 \\
\hline & Architectural drawings of places & 3 \\
\hline
\end{tabular}

When it examined table 6, teachers candidates' opinions about improving the perception of place in out-of-school social studies teaching; It appears to be grouped under two themes " "strategy" and " activity". Teacher candidates' views under the theme "strategy"; "Developing imagination of students" (10), "organizing activities appropriate to the age of the students" (6), "teaching from concrete to abstract" (6), "1magining the place visited to the students during abstract stage" (6), "learning the story of places" (2). "teacher candidates 'views under the theme "activitiy"; "making activity on real places" (27), "using map compass and location direction finding with orienteering activity" (25), "organizing activities for the remote environment starting from the immediate surroundings" (11), "using three-dimensional images in the courses" (10), "interpretation of photos" (9), "drawing of real places" (6), "environmental examination" (5), "architectural drawings of places" (3).

The answers of the teacher candidates in the development of the perception of place, organizing teaching appropriate to the age of the students ve to make observations on the places in these teaching, painting and architectural drawings of these places, Using map compass and location direction finding with orienteering activity, also it is observed that these places concentrate on activities suitable for out-of-school learning in the form of learning by students of their backgrounds. According to this result, the activities carried out in the project are parallel to the strategies and methods mentioned in the literature in developing the students' ability to perceive the place and it shows that the activities carried out within the scope of the project are effective in teaching the ability to perceive the place. Teachers' candidates' answers improving on place perception skills are as follows:

"In order to create the perception of place in students, it need to take students to different places and to develop their intelligence" (S1, M). 
"By passing through different places, students create various collages in their minds and support the formation of bonds with clues" (S2, M).

"They may be asked to organize and identify the place and non-place assets and fill them in their worksheet" (S3, M).

"...In activities, they are asked to picture the place and give a map and show your location on the map...." (S8, F).

"...People who lived in that place are made to talk to people..." $(\mathrm{S} 12, \mathrm{~F})$.

"...It can be created by using 3D-dimensional images to take advantage of simulation activities..." (S13, M).

"...By examining the structure of a mountain by the sea, the fossil remains between the layers formed there are predicted the years of formation..." (S20, F).

"...To have knowledge about the general situation of the place..." (S24, M).

"...By making street neighborhood city country drawings and discussing the differences between them..." (Ö25, F).

"...With the principle of proximodistal, the student is first introduced to the places he / she knows where he / she lives and then to the remote places..." (S26. M).

"...Orientring is an activity that anyone who can walk and run can do. The aim is to find directions and map reading and to recognize geographical features..." (S29, F).

"...The appropriate places according to the age of the students Castle, Mansion, Bridge, museum, and theatre, national parks, museums and madrasas are shown. At these places, drawings are made and worksheets are filled. Photographs are taken, comparisons are made, and people's lives are associated with the tools here..." (S30, F).

\section{Discussion}

In order to develop the spatial perception skills that the social studies curriculum aims to gain for the students, the individual should play an active role in that place and act primarily within it. Thanks to the movement, various images are accumulated in the mind and a spatial relationship network is started to be established. In the literatüre, the spatial perception skills are stated to be a skill that can be developed through an active process of reading environmental information through a mental process with the help of sensing, hearing, tasting, seeing, sniffing, touching and feeling of abstract and concrete objects (Asar, 2013). In this study, it is aimed to determine the effectiveness of out-ofschool applications for teaching the concept of place, perception of place and perception of place in social studies teaching according to the opinions of the teacher candidates and to create an example of teaching effectiveness for the practitioners. During the research, various activities, object-based studies, architectural drawings and observations on historical and geographical locations were carried out in accordance with the constructivist education system.

As a result of the analysis of the data, it was observed that teacher candidates ' perceptions of place were formed under two themes: "artificial and natural places". Teacher candidates gave examples of artificial places; living place, house, where people's habitats are located, cities, buildings, streets. in terms of the theme of natural places; universe, area of human, animals and plants, solar system, planets, moon and earth, mountains, they have indicated larger places. When the opinions given here are evaluated, it is understood that the teacher candidates generally associate the concept of 
place with living things and see them as places where living things can live and as perceptible places.

It is observed that the definitions of place in the literature are similar to the definitions of place for the teacher candidates. (Montello 1993; Roth, 2000; Avar, 2009; TLI, 2018). According to this conclusion, it can be said that the work carried out outside the school is effective in improving the students ' perception of place in social studies class. Uğurlu and Aladağ (2015) received teacher views on different dimensions of spatial thinking and performed them as case studies, the findings of" students to know their immediate environment"," close away principle "and" students to interact with real place" are paralleled with the results of this research.

When the findings related to similar aspects of place, landscape and landscape concepts are evaluated; all three concepts are related to the environment, the concept of place covers all three concepts, it has been found that all three concepts represent the existence of a place and all express opinions that are perceptible. The teacher candidates ' views on the different aspects of the concepts of place, landscape and landscape are combined under three themes: place-scene, place-landscape and scene-landscape. The teacher candidates stated that the concept of place covers the concept of landscape and scene, that the landscape is natural, that the landscape is arranged to make a place look pleasant to the eye, and that the scene is a beautiful-looking image of nature.

Joa, Hongb and Verma (2016) have revealed that there is improvement in spatial thinking skills related to abstract thinking in students doing landscape analysis with web-based geographic information systems. However, they also stated that spatial thinking can be improved without using geographic information systems.

Findings on the ability of individuals with the perception of place to understand and interpret events are discussed under three themes: comprehension, interpretation and mental activities. Students with the theme of understanding the sense of place within, the place of living on social, cultural and economic able to examine different aspects of their situation, the details of a place able to be aware of different perspectives and understand the factors which affect the feelings and thoughts of living in those places they can grasp and place the findings were reached..

In terms of the theme of interpretation, students who have the perception of place can interpret events more easily and comprehensively, evaluate these events by knowing and understanding them, take into account the conditions of place when evaluating events, analyze geography according to cause and effect relationship and interpret place correctly by going from part to whole. Within the context of the theme of mental activities, it has been determined that the candidates of teachers; individuals who have the ability to perceive place; can organize activities from close to distant surroundings, have high imagination, are curious, develop concrete and abstract thoughts, can depict place, can think objectively, and develop world views, mental skills and inquiry skills. These findings are similar to those of individuals who have the ability to perceive place in the field (MoNE, 2005; Özen, 2006; Asar, 2013; Solak, 2017). According to this result, research activities can be said to be effective in developing place perception skills. 
In the research, findings on how to improve the perception of place in students in social studies teaching; it is given under two themes: strategy and activity. Organizing activities appropriate to the age of the students, Teaching from concrete to abstract, Imagining the place visited to the students during abstract stage, Learning the story of places, making activity on real places, using map compass and location direction finding with orienteering activity, organizing activities for the remote environment starting from the immediate surroundings, using three-dimensional images in the courses, interpretation of photos, drawing of real places, environmental examination, architectural drawings of places, they proposed the realization of such strategies, methods, techniques and activities. These findings are map drawing activities (Yazıc1, 2006), geographic information systems (Demirci and Karaburun, 2011), web-based geographic information systems (Joa, Hongb and Verma, 2016), animation and use of digital maps (Aktürk, Yazıcı and Bulut, 2013), spatial skills training (Özdemir, 2011), virtual land trips (Çalışkan, 2011), using the google earth program (Merç, 2017) it is similar to the findings of such research. It has been reported that students' perception of place develops with the activities carried out in the mentioned studies. However, the difference of this research from the said research is that the application is carried out on real places outside the school. In Uğurlu and Aladağ (2015) studies on how to teach the subjects related to spatial thinking teachers, projectors and smart boards, video, animation, maps, printed and three-dimensional materials, graphics with tools such as question \& answer lecture, giving examples, trip-observation and using methods and techniques such as brainstorming, students skills can be developed in the form of place detection has revealed the specifications of vision. Lowrie, Logan, Harris and Hegarty (2018) a class-based spatial thinking program enriched by mathematical activities, in their experimental study, which evaluated the effects of Secondary School students on spatial thinking skills, they determined that students' spatial thinking skills increased more than the control group. Ormand et al (2014) stated that undergraduates studying in different departments have different spatial skills and that spatial skills can be improved by practice, revealing that some skills develop more in some people. In the studies, it is observed that the effects of the studies carried out in the classroom are investigated intensively in the development of the students' perception skills. In this study, the teacher candidates stated that they were able to recognize the place, objects and assets around them through activities outside the school and developed their perception skills by applying them. In the light of the results of the research, the following suggestions may be made:

- Activities on real places outside the school can be diversified in order to improve the perception of the place.

- Teaching skills can be given importance in education faculties.

- Methods and techniques teaching can be developed practically in faculties of education.

- Out-of-school activities can be used to gain the skills to perceive the place in social studies class.

- Teachers can be given seminars on the planning, execution and skill teaching of out-of-school activities. 


\section{References}

Aktürk, V. (2012). The effects of using animation and digital map for students? capabilities to perceive the place in social studies lesson. Unpublished postgraduate thesis. Afyon Kocatepe Universty, Afyon.

Aktürk, V., Yazıcı, V., \& Bulut, R. (2013). The effects of the use of animations and digital maps in social studies on students' spatial perception skills. Marmara Geographical Review. 28, 1-17.

Altın, B. N., \& Demirtaş, S. (2009). Sosyal bilgiler eğitiminde sınıf dışı etkinlikler (müze ve arazi çalışmaları). In M. Safran (Ed.), Sosyal Bilgiler Öğretimi (pp. 507- 541). Ankara: Pegem Akademi.

Asar, H. (2013). Examination of the analysis of perceptional experience in architectural place reading with the help of a method. Unpublished postgraduate thesis, Eskişehir Osmangazi University, Eskişehir.

Avar, A. A. 2009, Lefebvre'in üçlü- algılanan, tasarlanan, yaşanan mekan- diyalektiği. Mimarlık ve Mekan Algist. 17, 7-16.

Baksi, S. (2018). Investigation of children's spatial perception in the living environment. Unpublished postgraduate thesis. Selçuk University, Konya.

Büyüköztürk, Ş., Kılıç Çakmak, E., Akgün Ö. E., Karadeniz Ş., \& Demirel, F. (2011). Bilimsel araştırma yöntemleri. (9th edit.), Ankara: Pegem Akademi.

Çalışkan, O. (2011). Virtual field trips in education of earth and environmental sciences. Ankara University Journal Of Faculty Of Educational Sciences, 44 (19), 91-106.

Creswell, J. W. (2017). Nicel ve nitel araştırmanın planlanmast, yürütülmesi ve değerlendirilmesi. Ekşi, H. (Translate Ed.), Ankara: Eğitim Danışmanlığ Araştırmaları Merkezi.

Çukur, D., \& Güller Delice, E. (2011). Designing place suitable for development of visual perception in preschool childhood. Aile ve Toplum Ylllı̆̆

Çulha, B. (2006). Students'ideas about teaching social studiea at historical places through discovery learning. Unpublished postgraduate thesis. Dokuz Eylül University, İzmir.

Demirci, A., \& Karaburun, A. (2011). Using GIS, GPS, and google earth technologies in geography lessons. Marmara Geographical Review, 24, 99-123.

Gandy, S. K. 2007. "Developmentally appropriate geography." social studies and the young $\begin{array}{lllll}\text { learner } & 20 & \text { (2): } & 30-32 . & \text { Retrieved }\end{array}$ https://www.socialstudies.org/system/files/publications/articles/yl_200230.pdf 20.04.2019.

Gezer, H. 2012. Components of perception during the process of place perception. Istanbul Commerce University Journal of Social Science, 11 (21), 1-10.

Gold, A.U., Pendergast, P.M., Ormand, C.J., Budd, D.A., Stempien, J.A., Mueller, K.J., \& Kravitz, K.A. (2018). Spatial skills in undergraduate students-Influence of gender, motivation, academic training, and childhood play. Geosphere, 14 (2), 668-683. doi:10.1130/GES01494.1.

Golledge, R. G., Stimson, R. J. (1997). Spatial behavior: A geographic perspective. Guilford Press. New York. 
Hasol, D. (2016). Ansiklopedik mimarlık sözlüğ̈̈. (12th edit.), İstanbul: Yem. Retrieved from http://www.tdk.gov.tr/index.php?option=com_gts\&arama=gts\&kelime=mek\%C3\%A2n\& uid $=35221 \&$ guid=TDK.GTS.5c5c4853c92286.47577535.

Hespanha, S. R., Goodchild, F., \& Janelle, D. G. (2009). Spatial thinking and technologies in the undergraduate social science classroom. Journal Of Geography In Higher Education, 33 (1), 17-27.

İnceoğlu, M. (2011). Tutum algı iletişim. (6th edit.), Ankara: Siyasal Kitabevi.

Ishikawa, T. (2016). Spatial thinking in geographic information science: students' geospatial conceptions, map-based reasoning, and spatial visualization ability. A final of the American Association of Geographers, 106 (1), 76-95.

Joa, I., Hongb, J. E., \& Verma, K. (2016). Facilitating spatial thinking in world geography using webbased GIS. Jurnal of Geography In Higher Education, 40 (309), 17-27. http://dx.doi.org/10.1080/03098265.2016.1150439.

Kan, A. Ü. (2012). The effects of using individual and group mind mapping on students' academic achievement, retention and affective characteristics in social studies course. Unpublished doctorate thesis, Firat University, Elazığ.

Lowrie, T., Logan, T., Harris, D., \& Hegarty, M. (2018). The impact of an intervention program on students' spatial reasoning: student engagement through mathematicsenhanced learning activities. Cognitive Research: Principles and Implications. 3 (50), 1-10. doi.org/10.1186/s41235-018-0147-y.

Merç, A. (2017). The effectiveness of Google Earth in the acquisition of spatial perception ability in social studies courses. Unpublished doctorate thesis, Anadolu University, Eskişehir.

Miles, M. B., \& Huberman, A. M. (2016). Nitel veri analizi. (2nd edit). S. Akbaba Altun, \& A. Ersoy (Eds.). Ankara: Pegem Akademi.

Milli Eğitim Bakanlığı. (2005). İlköğretim sosyal bilgiler dersi ögretim programı ve kılavuzu (4-5. siniflar), Ankara.

Milli Eğitim Bakanlığı. (2018). Sosyal bilgiler dersi ögretim programı (İlkokul ve ortaokul 4, 5, 6 ve 7. siniflar). Ankara.

Milson, A.J., \& Earle, B.D. (2008). Internet-based GIS in an inductive learning environment: a case studyof ninth-grade geography students. Journal of Geography, 106, (6), 227-237.

Montello, D. R. (1993). Scale and multiple psychologies of place. In A. U. Frank \& I. Campari (Eds.), Spatial information theory: A theoretical basis for GIS (pp. 312-321). Proceedings of COSIT '93. Berlin: Springer-Verlag, Lecture Notes in Computer Science 716.

National Curriculum Standards for Social Studies (2014). The themes of social studies published on national council for the social studies, Retrieved from http://www.socialstudies.org.

Öcal, A. (2009). 6 th grades student's interpreting of aerial photographs. Ahi Evran University Journal of Kırşehir Education Faculty, 10 (1), 103-111.

Öcal, A. (2011). Sosyal bilgilerde mekansal biliş becerisi ve öğretimi. In B. Tay \& A. Öcal (Eds.). Özel ögretim yöntemleriyle sosyal bilgiler ögretimi (pp. 371-398). Ankara: Pegem Akademi.

Öğütveren, M. (2014). The influence of google earth software on the success of teaching 
geographical topics for the 6th grade students. Unpublished postgraduate thesis, Giresun Universty, Giresun.

Ormand, C. J., Manduca, C., Shipley, T. F., Tikoff, B., Harwood, C. L., Atit, K., \& Boone, A. P. (2014). Evaluating geoscience students' spatial thinking skills in a multiinstitutional classroom study. Journal of Geoscience Education, 62, 146-154.

Özdemir, A. A. (2011). The effect of spatial skill education program on spatial skills of preschool children's. Unpublished doctorate thesis, Marmara Universty, İstanbul.

Özen, A., (2006). Mimari sanal gerçeklik ortamlarında alg1 psikolojisi”, Bilgi Teknolojileri Kongresi IV, Akademik Bilişim, Denizli. Retrieved from http://ab.org.tr/ab06/bildiri/81.doc,4/6/2012 .

Paykoç, F. (1991). Tarih öğretimi. Eskişehir: Anadolu Üniversitesi Açıöğretim Press.

Roth, L. M. (2000) Mimarlığın öyküsü, E. Akça (Trans.), İstanbul: Kabalcı Press.

Schultz, R. B., Kerski, J. J., \& Patterson, T. C. (2008). The use of virtual globes as a spatial teaching tool with suggestions for metadata standards. Journal of Geography, 27-34. Retrieved from https://www.researchgate.net/publication/249043796_The_Use_of_ Virtual_Globes_as_a_Spatial_Teaching_Tool_with_Suggestions_for_Metadata_Standard s.

Şengül Bircan, T., \& Safran, M. (2013). The usage and the importance of maps in teaching history. Ahi Evran University Journal of Kırşehir Education Faculty, 14 (2), 461-476.

Solak G. S. (2017). Place-identity interaction: a conceptual and theoretical overview. Manas Journal Of Social Studies. 6 (1), 13-37.

Taş, H. İ. (2008). Zihin haritaları, harita okuma becerisi ve görselleştirme. In R. Özey (Ed.). Coğrafya ögrretiminde yöntem ve yaklaşımlar (pp. 133-170). Ankara: Aktif.

Türk Dil Kurumu. (2018). Retrieved from www.tdk.gov.tr.

Uğurlu, N. B., Aladağ, E. (2015). The placing of spatial thinking in turkish social studies education and social studies teachers' opinion about this issue. Marmara Geographical Review, 32, 22-42.

Yazıc1, K. (2006). Visual tools used in social studies: maps-spheres, images, tables and graphs. Selçuk University Journal of Social Sciences Institute, 15, 651-662.

Yıldırım, A., \& Şimşek, H. (2016). Sosyal bilimlerde nitel araştırma yöntemleri. (11th edit.), Ankara: Seçkin.

Yin, R. K. (2017). Durum çalışması araştırması uygulamaları. (3rd edit.), K. Günbayı (Ed.). Ankara: Nobel.

\section{Biographical Statement}

Ayşe SEYHAN is Assistant Professor at the Department of Turkish and Social Studies Education/ Recep Tayyip Erdoğan University/Turkey. Her studying area focuses on learning and teaching in social studies, out-of-school learning and colloborative learning. 